\title{
KEKUATAN BETON SERAT KAWAT GALVANIS
}

\author{
Karmila Achmad $^{1^{*}}$, Sunarno ${ }^{2}$ \\ ${ }^{1}$ Politeknik Negeri Balikpapan \\ ${ }^{2}$ Politeknik Negeri Balikpapan \\ *karmila.achmad@poltekba.ac.id
}

\begin{abstract}
Fibers in concrete prevent crack creating the concrete become stronger compared to the concrete without fibers. Galvanized wire is widely used because it is cheap, easy to form and maintain. The galvanized wire can be implemented for concrete fiber to delay the concrete failure due to the load. This research aims to obtain the shape of the synthetic fiber of galvanized wire that is cheap and can increase the concrete strength optimally with regards to compressive, tension and bending strength. In this experiment, the shape of the fiber that were used are rolled and crimped. The result shows that the sample with rolled fiber shape produced higher strength than the crimed fiber shape. The smaller the diameter of the rolled fiber shape, the stronger the concrete. Sample L2 (rolled 2) produced 27,57MPa, 22,84 MPa, 10,11 MPa and 5,42 MPa for 14-day compressive strength, 28-day compressive strength, tension strength and bending strength respectively.
\end{abstract}

Keywords : fiber shape, galvanized wire, local material, Samboja sand

\begin{abstract}
Abstrak
Serat dalam beton berfungsi mencegah retak-retak sehingga menjadikan beton lebih kuat daripada beton tanpa serat. Kawat galvanis banyak digunakan karena murah, mudah dibentuk dan mudah perawatannya. Kawat galvanis ini dapat dimanfaatkan pada pembuatan beton serat yang berfungsi untuk menunda keruntuhan beton akibat beban yang bekerja. Tujuan penelitian ini adalah untuk mendapatkan bentuk serat buatan berupa kawat galvanis yang relatif murah dan mampu meningkatkan kekuatan beton secara optimal ditinjau dari kuat tekan, kuat tarik maupun kuat lentur. Dalam penelitian ini bentuk galvanis yang digunakan adalah Linting dan Crimped. Hasil penelitian menunjukan bahwa benda uji dengan kawat galvanis bentuk Linting memberikan nilai kekuatan beton yang lebih baik dibandingkan Crimped. Semakin kecil diameter Linting akan memberikan kekuatan yang lebih baik dibandingkan diameter Linting yang lebih besar. Benda uji L2 (Linting 2) memiliki kekuatan 27,57 MPa, 22,84 MPa, 10,11 MPa dan 5,42 MPa masing-masing untuk uji tekan umur 14 hari, uji tekan 28 hari, uji tarik dan uji lentur balok.
\end{abstract}

Kata kunci : Bentuk Serat, Kawat galvanis, Material Lokal dan Pasir Samboja

\section{Pendahuluan}

\subsection{Beton Serat}

Beton serat adalah bahan komposit yang terdiri dari beton biasa dan bahan lain yang berupa serat. Serat dalam beton ini berfungsi mencegah retak-retak sehingga menjadikan beton lebih kuat daripada beton biasa. Bahan serat dapat berupa serat asbestos, serat plastik (poly-propyline), atau potongan kawat baja, serat tumbuh-tumbuhan seperti rami, sabut kelapa, bambu, dan ijuk.
Pembuatan beton serat adalah dengan menambahkan serat kedalam campuran beton, yang betujuan untuk meningkatkan kekuatan beton agar mampu menunda kehancuran beton. Banyak sifat-sifat beton yang dapat diperbaiki dengan penambahan serat seperti: meningkatnya daktilitas, ketahanan impact, meningkatnya kuat tarik dan lentur, ketahanan terhadap fatigue, ketahanan terhadap pengaruh susutan, ketahanan abrasi, ketahanan terhadap pecahan atau fragmentasi, ketahanan terhadap pengelupasan. 
Kawat galvanis merupakan material baja dan besi yang diberi pelapis seng untuk mencegah korosi. Seng merupakan logam yang relatif tahan karat, seng bekerja sebagai proteksi katodik yang melindungi baja. Kawat galvanis banyak digunakan karena murah dan mudah perawatannya. Kawat galvanis ini dapat dimanfaatkan pada pembuatan beton serat yang berfungsi untu menunda keruntuhan beton akibat beban yang bekerja.

Edy Purwanto, 2011 meneliti besar kemampuan beton ringan berserat kawat galvanis untuk menahan gaya lentur pada balok beton tanpa tulangan. Dengan variasi serat $0 \% ; 0,3 \% ; 0,75 \% ; 1 \%$ nilai kuat lentur yang diperoleh berturut-turut adalah $2,76 \mathrm{MPa}$; 3,17 $\mathrm{MPa} ; 3,78 \mathrm{MPa}$ dan 4,37 $\mathrm{MPa}$. Peningkatan kuat tekan terbesar terjadi pada variasi serat $1 \%$ yaitu $58,32 \%$. Penambahan persentase serat dalam campuran beton mampu meningkatkan kuat lentur dan kuat tekan beton. Dari hasil penelitian Basuki, 2013, disimpulkan bahwa kawat galvanis mampu meningkatkan kuat lentur pada balok beton bertulang dengan peningkatan kuat lentur sebesar $21,93 \%, 51,18 \%$ dan $70,52 \%$ masing-masing untuk diameter kawat galvanis $1,02 \mathrm{~mm} ; 1,29 \mathrm{~mm}$ dan 1,63mm. Ahmad Saifuddin, 2015 menyatakan bahwa semakin besar aspek rasio penambahan serat baja akan memberikan kinerja kuat tarik belah yang lebih baik. Untuk dosis serat $20 \mathrm{~kg} / \mathrm{m}^{3}, 40$ $\mathrm{kg} / \mathrm{m}^{3}, 60 \mathrm{~kg} / \mathrm{m}^{3}, 80 \mathrm{~kg} / \mathrm{m}^{3}$, diperoleh kuat tarik belah terbesar adalah $44,62 \%$ untuk dosis serat $80 \mathrm{~kg} / \mathrm{m}^{3}$. Penelitian yang dilakukan oleh Abdul Aziz, 2016 menghasilkan bahwa kuat tarik belah beton meningkat dengan penambahan dramix steel fiber, dengan peningkatan kuat tarik belah rata-rata adalah $41,4 \%$ untuk mutu beton $20 \mathrm{MPa}$ dan $24,48 \%$ untuk mutu beton $40 \mathrm{MPa}$.

\subsection{Tujuan}

Tujuan penelitian ini adalah untuk mendapatkan material serat buatan yang relatif murah dan mampu meningkatkan kekuatan beton secara optimal baik ditinjau dari segi kuat tekan, kuat tarik dan kuat lentur.

\section{Metoda Penelitian}

\subsection{Benda Uji}

Material agregat yang digunakan dalam penelitian ini adalah materil lokal pasir Samboja. Jenis serat yag digunakan berupa serat buatan dari kawat galvanis sepanjang $5 \mathrm{~cm}$, kawat galvanis yang dibentuk Linting dan Crimped. Dengan variasi benda uji, yaitu: Original $(\mathrm{O})$, Galvanis 5 cm (G), Linting 2 (L2), Linting 3 (L3), Linting 4 (L4) dan Linting 5 (L5), Crimped ф 0,6 cm (C06), Crimped $\phi 1 \mathrm{~cm}(\mathrm{C} 1)$, Crimped ф 1,6 cm (C16), dan Crimped ф $2 \mathrm{~cm}$ (C2). Serat yang digunakan seperti pada gambar 1 .
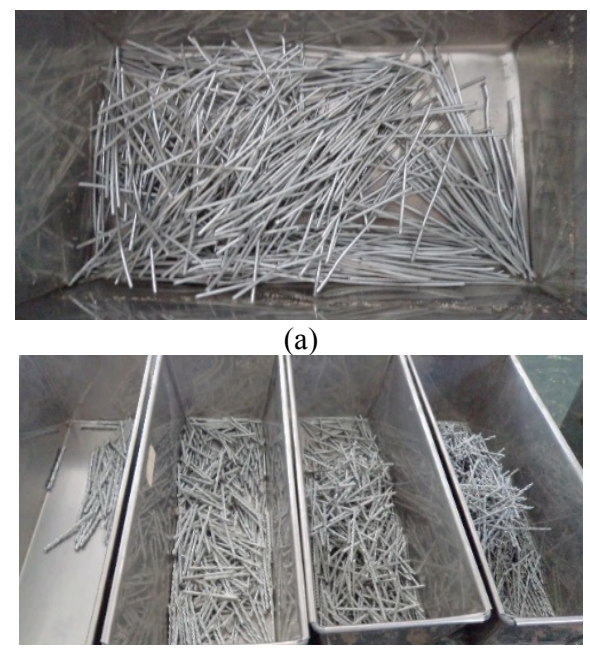

(b)

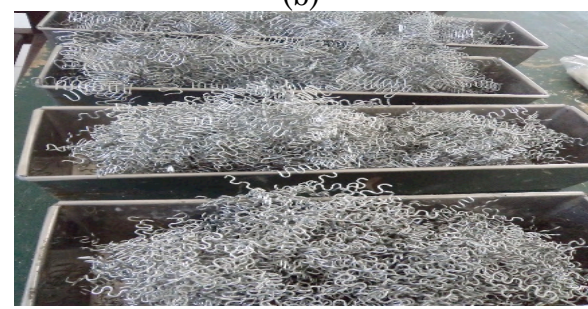

(c)

Gambar 1. Serat Kawat Galvanis: (a) Galvanis $5 \mathrm{~cm}$, (b) Bentuk Linting, dan (c) Bentuk Crimped

Pengujian yang dilakukan berupa uji tekan, uji tarik belah beton dan uji lentur balok beton. Jumlah benda uji silinder sebanyak 81 buah diuji tekan umur 14 hari, 28 hari dan uji tarik belah, benda uji balok 10x10x60 $\mathrm{cm}^{3}$ sebanyak 27 buah diuji lentur.

Seluruh variasi benda uji dilakukan pengulangan sebanyak 3 benda uji. Adapun rincian benda uji dapat dilihat pada tabel 1 . 
Tabel 1. Benda Uji Penelitian

\begin{tabular}{|c|c|c|c|c|c|}
\hline \multirow{2}{*}{$\begin{array}{l}\text { Kelompok } \\
\text { Benda Uji }\end{array}$} & \multirow{2}{*}{$\begin{array}{l}\text { Jenis } \\
\text { variasi }\end{array}$} & \multicolumn{4}{|c|}{$\begin{array}{c}\text { Kode Penamaan untuk Masing-Masing } \\
\text { Pengujian }\end{array}$} \\
\hline & & $\begin{array}{l}\text { Uji } \\
\text { tekan } \\
14 \text { hari }\end{array}$ & $\begin{array}{l}\text { Uji } \\
\text { tekan } \\
28 \text { hari }\end{array}$ & $\begin{array}{l}\text { Uji } \\
\text { tarik } \\
\text { belah }\end{array}$ & $\begin{array}{l}\text { Uji lentur } \\
\text { balok } \\
(10 \times 10 \times 60)\end{array}$ \\
\hline $\begin{array}{c}\text { Kawat } \\
\text { Galvanis }\end{array}$ & $\begin{array}{c}\text { panjang } 5 \\
\mathrm{~cm}\end{array}$ & $\begin{array}{l}\text { GA1- } \\
\text { GA3 }\end{array}$ & $\begin{array}{l}\text { GB1- } \\
\text { GB3 }\end{array}$ & $\begin{array}{l}\text { BG1- } \\
\text { BG3 }\end{array}$ & G1-G3 \\
\hline \multirow{4}{*}{$\begin{array}{c}\text { Variasi } \\
\text { diameter } \\
\text { lintingan } \\
\text { kawat } \\
\text { gavanis }\end{array}$} & $\begin{array}{l}\text { Linting } 2 \\
\text { galvanis }\end{array}$ & $\begin{array}{l}\text { L2A1- } \\
\text { L2A3 }\end{array}$ & $\begin{array}{l}\text { L2B1- } \\
\text { L2B3 }\end{array}$ & $\begin{array}{l}\text { BL21- } \\
\text { BL23 }\end{array}$ & L21-L23 \\
\hline & $\begin{array}{l}\text { Linting } 3 \\
\text { galvanis }\end{array}$ & $\begin{array}{l}\text { L3A1- } \\
\text { L3A3 }\end{array}$ & $\begin{array}{l}\text { L3B1- } \\
\text { L3B3 }\end{array}$ & $\begin{array}{l}\text { BL31- } \\
\text { BL33 }\end{array}$ & L31-L33 \\
\hline & $\begin{array}{l}\text { Linting } 4 \\
\text { galvanis }\end{array}$ & $\begin{array}{l}\text { L4A1- } \\
\text { L4A3 }\end{array}$ & $\begin{array}{l}\text { L4B1- } \\
\text { L4B3 }\end{array}$ & $\begin{array}{l}\text { BL41- } \\
\text { BL43 }\end{array}$ & L41-L43 \\
\hline & $\begin{array}{l}\text { Linting } 5 \\
\text { galvanis }\end{array}$ & $\begin{array}{l}\text { L5A1- } \\
\text { L5A3 }\end{array}$ & $\begin{array}{l}\text { L5B1- } \\
\text { L5B3 }\end{array}$ & $\begin{array}{l}\text { BL51- } \\
\text { BL53 }\end{array}$ & L51-L53 \\
\hline \multirow{4}{*}{$\begin{array}{c}\text { Variasi } \\
\text { tebal } \\
\text { kawat } \\
\text { galvanis } \\
\text { model } \\
\text { crinped }\end{array}$} & $\begin{array}{l}\text { diameter } \\
\text { luar } \\
\text { crimped } \\
0,6 \mathrm{~cm}\end{array}$ & $\begin{array}{l}\text { C06A1- } \\
\text { C06A3 }\end{array}$ & $\begin{array}{l}\text { C06B1- } \\
\text { C06B3 }\end{array}$ & $\begin{array}{l}\text { CS061- } \\
\text { CS063 }\end{array}$ & $\mathrm{C} 061-\mathrm{C} 063$ \\
\hline & $\begin{array}{l}\text { diameter } \\
\text { luar } \\
\text { crimped } 1 \\
\mathrm{~cm}\end{array}$ & $\begin{array}{l}\text { C1A1- } \\
\text { C1A3 }\end{array}$ & $\begin{array}{l}\text { C1B1- } \\
\text { C1B3 }\end{array}$ & $\begin{array}{l}\text { CS11- } \\
\text { CS13 }\end{array}$ & $\mathrm{C} 11-\mathrm{C} 13$ \\
\hline & $\begin{array}{l}\text { diameter } \\
\text { luar } \\
\text { crimped } \\
1,6 \mathrm{~cm}\end{array}$ & $\begin{array}{l}\text { C16A1- } \\
\text { C16A3 }\end{array}$ & $\begin{array}{l}\text { C16B1- } \\
\text { C16B3 }\end{array}$ & $\begin{array}{l}\text { CS161- } \\
\text { CS163 }\end{array}$ & C161-C163 \\
\hline & $\begin{array}{c}\text { diameter } \\
\text { luar } \\
\text { crimped } 2 \\
\mathrm{~cm} \\
\end{array}$ & $\begin{array}{l}\mathrm{C} 2 \mathrm{~A} 1- \\
\mathrm{C} 2 \mathrm{~A} 3\end{array}$ & $\begin{array}{l}\text { C2B1- } \\
\text { C2B3 }\end{array}$ & $\begin{array}{l}\mathrm{BC} 21- \\
\mathrm{BC} 23\end{array}$ & $\mathrm{C} 21-\mathrm{C} 23$ \\
\hline \multicolumn{2}{|c|}{ Jumlah benda uji } & 27 & 27 & 27 & 27 \\
\hline \multicolumn{2}{|c|}{ Total benda uji } & \multicolumn{4}{|c|}{108} \\
\hline
\end{tabular}

\subsection{Tahapan Pengujian}

Penelitian ini diawali dengan persiapan alat dan bahan, kemudian dilanjutkan dengan melakukan pengujian bahan agregat halus dan agregat kasar. Tahap ke tiga adalah degan melakukan mix desain untuk beton. Setelah mix desain didapatkan maka selanjutnya dilakukan pembuatan benda uji berupa silinder dan balok beton. Benda uji yang telah jadi kemudian dirawat dalam bak perendaman beton sebelum diuji tekan, tarik dan lentur. Tahapan terakhir dari penelitian ini adalah melakukan pengujian tekan, tarik dan lentur. Pengujian tekan dan tarik belah beton untuk benda uji silinder dan uji lentur untuk benda uji balok beton.
Tahapan pengujian seperti pada gambar 2 .

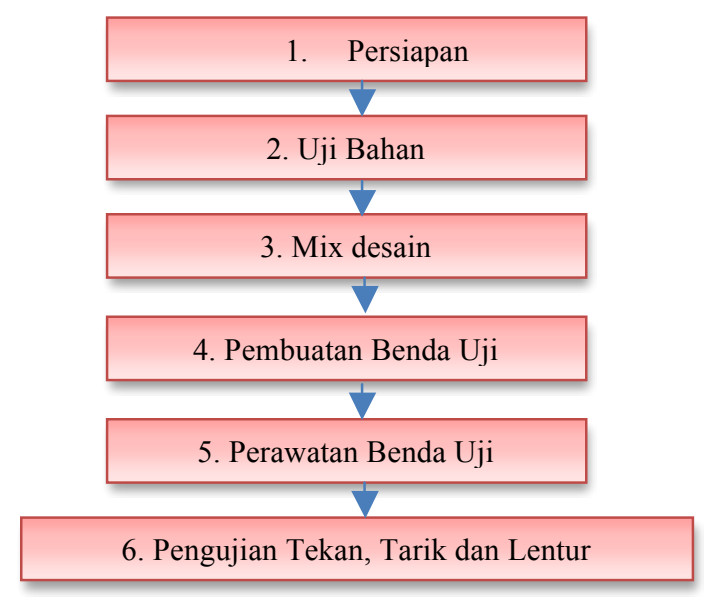

Gambar 2. Tahapan Penelitian

\section{Hasil Penelitian}

\subsection{Pengujian Bahan}

2.

Hasil pengujian bahan seperti pada Tabel

Tabel 2. Hasil Pemeriksaan Bahan

\begin{tabular}{llll}
\hline \multirow{2}{*}{ No } & Jenis Pemeriksaan & \multicolumn{2}{c}{ Hasil Pemeriksaaan } \\
\cline { 3 - 4 } & & $\begin{array}{l}\text { Agregat } \\
\text { Halus }\end{array}$ & $\begin{array}{l}\text { Agregat } \\
\text { Kasar }\end{array}$ \\
\hline 1 & Pemeriksaan Berat Jenis & & \\
\cline { 2 - 4 } & - Berat Jenis Curah & 1,74 & 2,72 \\
\cline { 2 - 4 } & - Berat Jenis Jenuh Kering & 2,04 & 2,73 \\
& Permukaan & 2,62 & 2,74 \\
\cline { 2 - 4 } & - Berat Jenis Semu & 4,69 & 0,26 \\
\cline { 2 - 4 } & - Penyerapan & 4,38 & 0,86 \\
\hline 2 & Kadar Air & 1,5 & 0,31 \\
\hline 3 & Kadar Lumpur & 1,18 & 7,08 \\
\hline 4 & Modulus Halus Butir & 1,24 & 1,61 \\
\hline 5 & Berat Isi & 1,34 & 1,72 \\
\hline & - Shoveling & - & $15,30 \%$ \\
\hline & - Rodding & & \\
\hline 6 & Keausan & & \\
\hline
\end{tabular}

\subsection{Uji Tekan Umur 14 Hari}

Dari hasil uji tekan beton umur 14 hari maka diperoleh nilai kuat tekan beton terbesar adalah untuk benda uji dengan penambahan galvanis model linting yaitu L2A dengan nilai kuat tekan beton sebesar 27,68 $\mathrm{MPa}$ dengan 
peningkatan kuat tekan sebesar 39,59\% dari beton tanpa penambahan galvanis. Secara rinci hasil kuat tekan beton dapat dilihat pada tabel 3 dan gambar grafik 4 .

Tabel 3. Hasil Uji Tekan Umur 14 Hari

\begin{tabular}{cccc}
\hline $\begin{array}{c}\text { Benda } \\
\text { Uji }\end{array}$ & $\begin{array}{c}\text { Nilai } \\
\text { Kuat } \\
\text { Tekan } \\
\text { (Mpa) }\end{array}$ & $\begin{array}{c}\text { Peningkatan } \\
\text { Kuat Tekan } \\
\text { Beton } \\
\text { Terhadap OA } \\
(\%)\end{array}$ & $\begin{array}{c}\text { Peningkatan } \\
\text { Kuat Tekan } \\
\text { Beton } \\
\text { Terhadap } \\
\text { GA (\%) }\end{array}$ \\
\hline OA & 19,83 & 0 & 0 \\
\hline GA & 19,76 & $-0,35$ & 0 \\
\hline L2A & 27,68 & 39,59 & 40,08 \\
\hline L3A & 24,27 & 22,39 & 22,82 \\
\hline L4A & 20,58 & 3,78 & 4,15 \\
\hline L5A & 18,89 & $-4,74$ & $-4,4$ \\
\hline C06A & 26,42 & 33,23 & 33,7 \\
\hline C1A & 25,71 & 29,65 & 30,11 \\
\hline C16A & 24,97 & 25,92 & 26,37 \\
\hline C2A & 22,63 & 14,12 & 14,52 \\
\hline
\end{tabular}

Untuk benda uji penambahan galvanis model crimped menunjukan bahwa semakin lebar crimped maka nilai kuat tekan semakin kecil, meskipun secara keseluruhan penambahan crimped meningkatkan nilai kuat tekan beton.

Dari model galvanis yaitu linting dan crimped menunjukan bahwa pengaruh masing-masing variasi di tiap modelnya memiliki peranan dalam peningkatan kuat tekan beton. Dan peningkatan kuat tekan cukup besar terdapat pada variasi benda uji model linting. Hasil benda uji yang telah diuji tekan seperti pada gambar 3 .

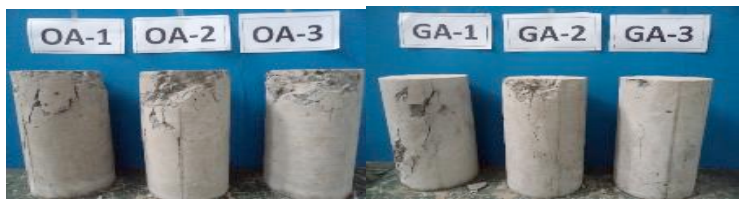

(a)

(b)

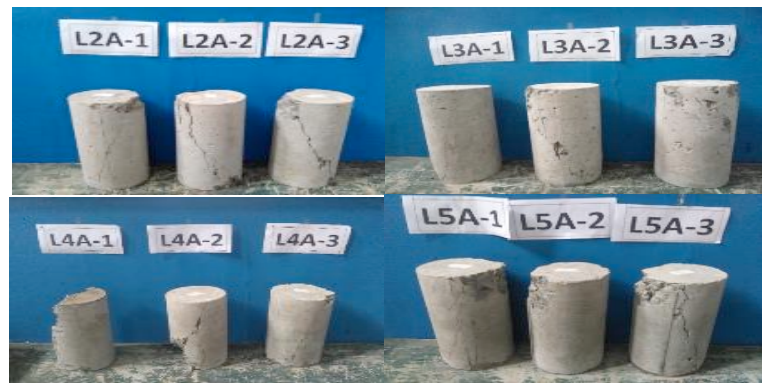

(c)

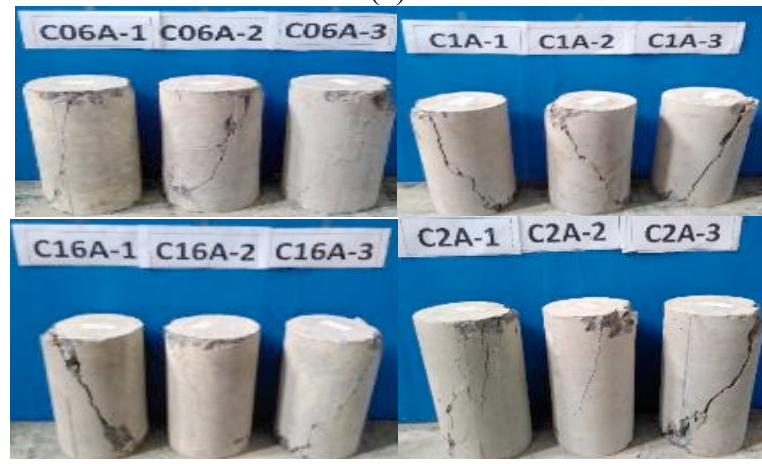

(d)

Gambar 3. Silinder Beton Setelah Uji Tekan Umur 14 Hari: (a) Beton Normal, (b) Galvanis, (c) Linting dan (d) Crimped

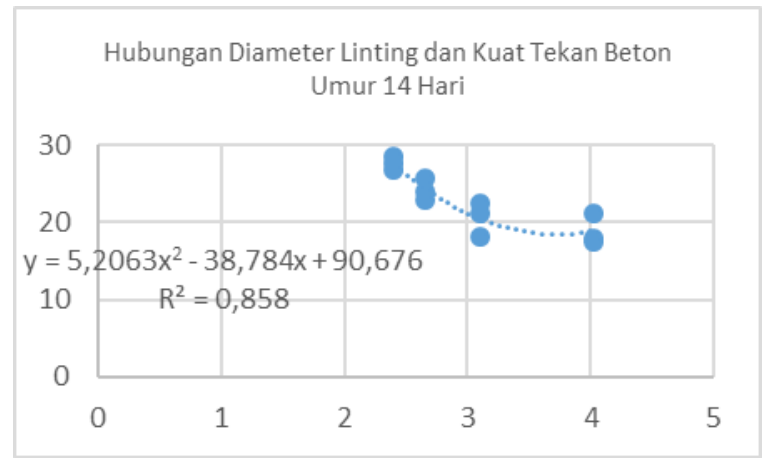

(a)

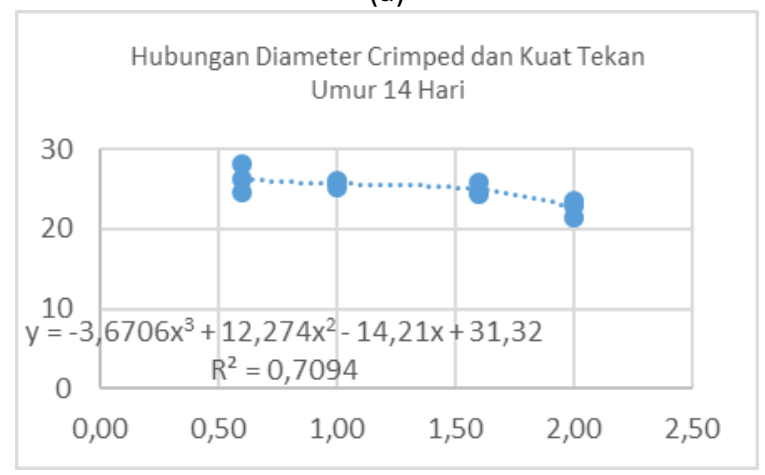

(b)

Gambar 5.2. Grafik Tren Kuat Tekan Umur 14 Hari: (a)

Benda Uji Linting dan (b) Benda Uji Crimped

Dari grafik pada gambar $4 \mathrm{a}$, diperoleh persamaan 
$y=5,2063 x^{2}-38,784 x+90,676$ dengan

$R^{2}=0,858$. Sehingga didapat kuat tekan ratarata umur 14 hari untuk tiap-tiap variasi adalah $27,57 \mathrm{MPa}, 24,46 \mathrm{MPa}, 20,48 \mathrm{MPa}$ dan 18,90 MPa untuk L2, L3, L4 dan L5. Dari grafik pada gambar $4 \mathrm{~b}$, diperoleh persamaan $y=-3,6706 x^{3}+12,274 x^{2}-14,21 x+$

\section{1,32}

dengan $R^{2}=0,7094$. Sehingga didapat kuat tekan rata-rata umur 14 hari untuk tiap-tiap variasi adalah 26,42 $\mathrm{MPa}, 25,1 \mathrm{MPa}, 24,97$ MPa dan 22,63 MPa untuk C06, C1, C16 dan C2.

\subsection{Uji Tekan Umur 28 Hari}

Dari hasil uji tekan beton umur 28 hari maka diperoleh nilai kuat tekan beton terbesar adalah untuk benda uji dengan penambahan galvanis model linting yaitu L2B dengan nilai kuat tekan beton sebesar 22,40 MPa dengan peningkatan kuat tekan sebesar $22,40 \%$ dari beton tanpa penambahan galvanis. Secara rinci hasi kuat tekan beton dapat dilihat pada tabel 4 dan gambar grafik 6 .

Tabel 4. Nilai Kuat Tekan Beton Umur 28 Hari

\begin{tabular}{|c|c|c|c|}
\hline $\begin{array}{c}\text { Benda } \\
\text { Uji }\end{array}$ & $\begin{array}{c}\text { Nilai } \\
\text { Kuat } \\
\text { Tekan } \\
\text { (MPa) }\end{array}$ & $\begin{array}{c}\text { Peningkatan } \\
\text { Kuat Tekan } \\
\text { Beton } \\
\text { Terhadap } \\
\text { OB (\%) }\end{array}$ & $\begin{array}{c}\text { Peningkatan } \\
\text { Kuat Tekan } \\
\text { Beton } \\
\text { Terhadap } \\
\text { GB (\%) }\end{array}$ \\
\hline OB & 18,3 & 0 & 0 \\
\hline GB & 18,08 & $-1,2$ & 0 \\
\hline L2B & 22,4 & 22,4 & 23,89 \\
\hline L3B & 21,82 & 19,23 & 20,69 \\
\hline L4B & 18,25 & $-0,27$ & 0,94 \\
\hline L5B & 17,85 & $-2,46$ & $-1,27$ \\
\hline C06B & 18,93 & 3,44 & 4,7 \\
\hline C1B & 19,51 & 6,61 & 7,91 \\
\hline C16B & 19,41 & 6,07 & 7,36 \\
\hline C2B & 21,88 & 19,56 & 21,02 \\
\hline
\end{tabular}

Gambar 5 menunjukan benda uji setelah uji tekan umur 28 hari.

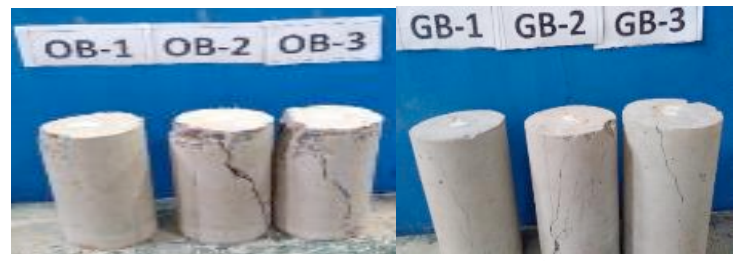

(a)

(b)

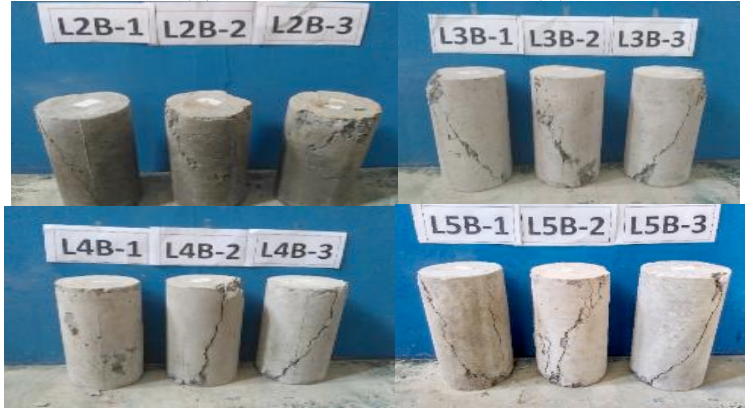

(c)

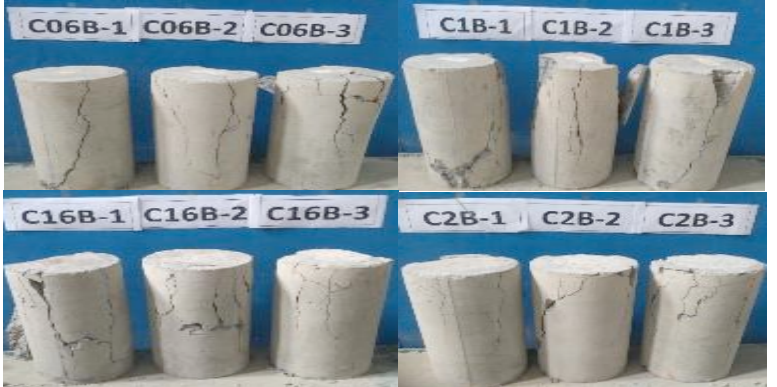

(d)

Gambar 5. Silinder Beton Setelah Uji Tekan Umur 28 Hari: (a) Beton Normal, (b) Galvanis $5 \mathrm{~cm}$, (c) Linting dan (d) Crimped

Dari grafik 6, tren yang terjadi pada masing-masing model dari benda uji dengan penambahan galvanis. Untuk benda uji dengan penambahan galvanis model linting terlihat bahwa banyak linting akan mempengaruhi nilai kuat tekan, dengan semakin banyak jumlah linting maka nilai kuat tekan akan semakin kecil. Pada benda uji penambahan galvanis model crimped menunjukan bahwa semakin lebar crimped maka nilai kuat tekan semakin besar. Kuat tekan terbesar pada benda uji C2B yaitu sebesar 19,56 MPa dengan peningkatan kuat tekan sebesar 19,56\% terhadap benda uji tanpa galvanis. 
Hubungan Diameter Linting dan Kuat Tekan Umur 28 Hari

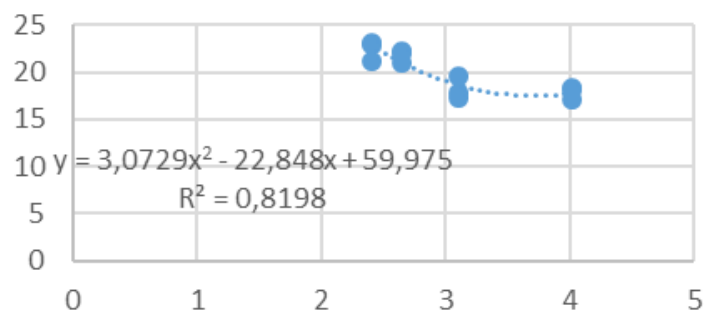

(a)

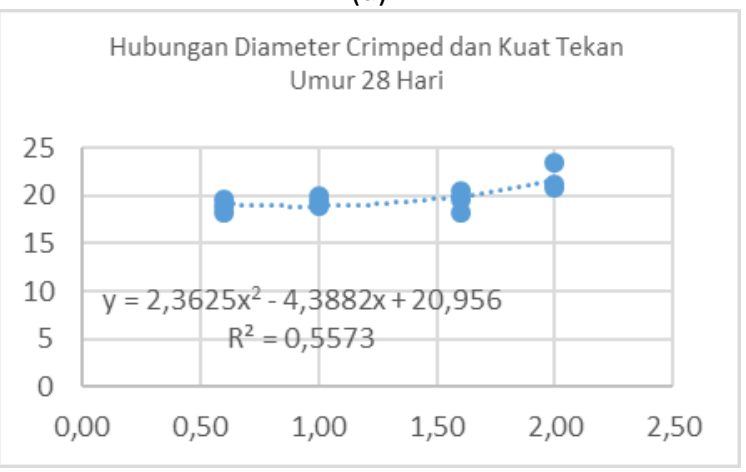

(b)

Gambar 6. Grafik Tren Kuat Tekan Umur 28 Hari: (a) Benda Uji Linting dan (b) Benda Uji Crimped

Pada gambar 6a, diperoleh persamaan $y=3,0729 x^{2}-22,848 x+59,975$ dengan $R^{2}=0,8198$. Sehingga didapat kuat tekan rata-rata umur 28 hari untuk tiap-tiap variasi adalah 22,84 Mpa, 21,01 Mpa, 18,68 Mpa dan 17,79 Mpa untuk L2, L3, L4 dan L5. Dari gambar 6b, diperoleh persamaan $y=2,3625 x^{2}-4,3882 x+20,956$ dengan $R^{2}=0,5573$. Sehingga didapat kuat tekan rata-rata umur 28 hari untuk tiap-tiap variasi adalah 19,17 Mpa, 18,93 Mpa, 19,98 Mpa dan 21,63 MPa untuk C06, C1, C16 dan C2.

\subsection{Kuat Tarik Beton}

Dari hasil uji tarik belah beton umur 28 hari maka diperoleh nilai kuat tarik beton terbesar adalah untuk benda uji dengan penambahan galvanis model crimped yaitu $\mathrm{BC} 1$ dengan nilai kuat tarik beton sebesar $10,44 \mathrm{MPa}$ dengan peningkatan kuat tarik belah sebesar $21,68 \%$ dari beton tanpa penambahan galvanis dan meningkat sebesar $10,73 \%$ dari benda uji dengan penambahan galvanis. Hasil persentase peningkatan kuat tarik seperti pada tabel 5.
Tabel 5. Kuat Tarik Beton

\begin{tabular}{|c|c|c|c|}
\hline $\begin{array}{c}\text { Benda } \\
\text { Uji }\end{array}$ & $\begin{array}{c}\text { Nilai } \\
\text { Tarik } \\
\text { Belah } \\
\text { (Mpa) }\end{array}$ & $\begin{array}{c}\text { Peningkatan } \\
\text { Kuat Tarik } \\
\text { Belah } \\
\text { Beton } \\
\text { Terhadap } \\
\text { BO (\%) }\end{array}$ & $\begin{array}{c}\text { Peningkatan } \\
\text { Kuat Tarik } \\
\text { Belah } \\
\text { Beton } \\
\text { Terhadap } \\
\text { BG (\%) }\end{array}$ \\
\hline BO & 8,58 & 0 & 0 \\
\hline BG & 10,26 & 19,58 & 0 \\
\hline BL2 & 10,28 & 19,81 & 1,17 \\
\hline BL3 & 9,79 & 14,1 & $-27,99$ \\
\hline BL4 & 10,11 & 17,83 & $-8,94$ \\
\hline BL5 & 8,83 & 2,91 & $-85,14$ \\
\hline BC06 & 10,37 & 20,86 & 6,54 \\
\hline BC1 & 10,44 & 21,68 & 10,73 \\
\hline BC16 & 10,18 & 18,65 & $-4,75$ \\
\hline BC2 & 9,63 & 12,24 & $-37,49$ \\
\hline
\end{tabular}

Gambar 7 adalah gambar benda uji yang telah diuji tarik belah.

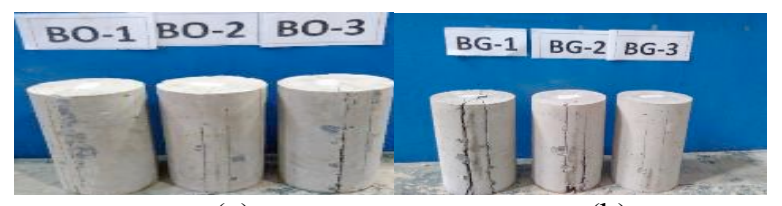

(a)

(b)

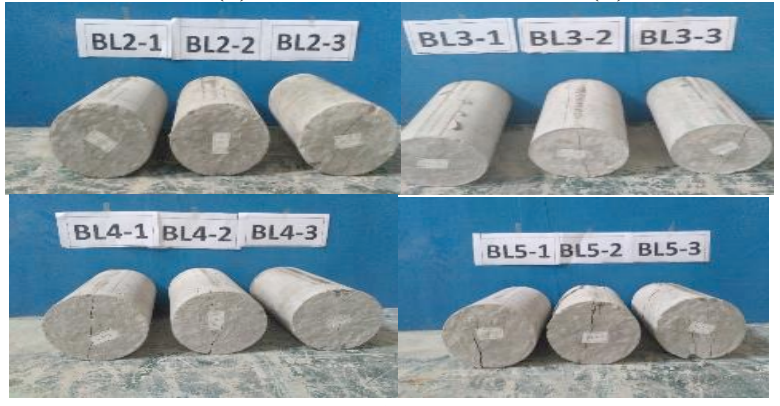

(b)

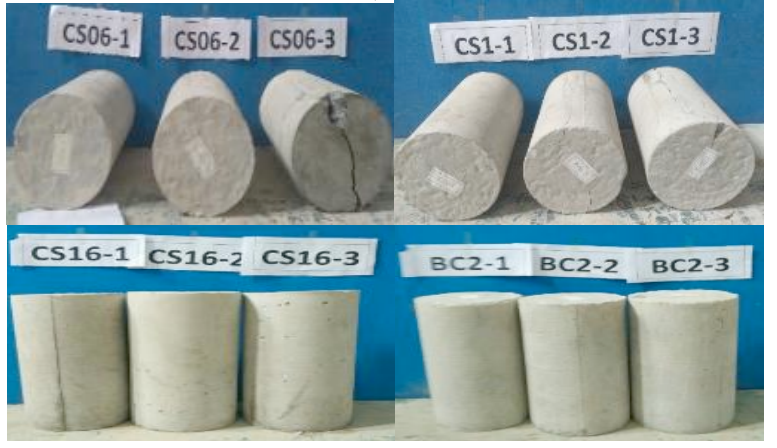

(c)

Gambar 7. Silinder Beton Setelah Uji Tarik belah: (a) Beton Normal, (b) Galvanis $5 \mathrm{~cm}$, (c) Linting dan (d) Crimped 
Hubungan Diameter Linting dan Kuat Tarik Belah Beton

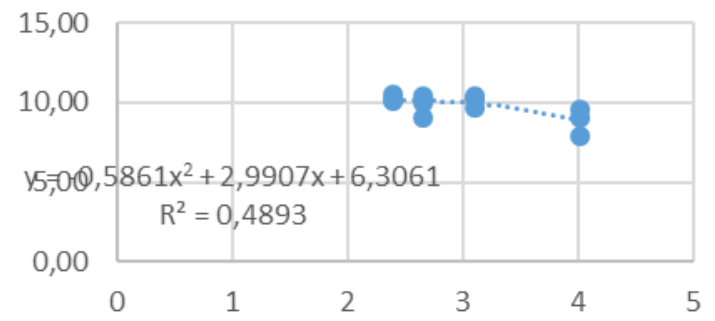

(a)

Hubungan Diameter Crimped dan Kuat Tarik Belah Beton

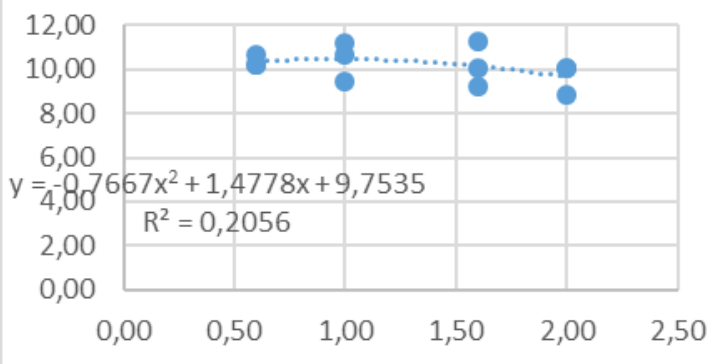

(b)

Gambar 8. Grafik Tren Kuat Tarik Belah: (a) Benda Uji Linting dan (b) Benda Uji Crimped

Pada gambar 8a diperoleh persamaan $y=-0,5861 x^{2}+2,9907 x+6,3061$ dengan $R^{2}=0,4893$. Sehingga didapat kuat tarikbelah tiap-tiap variasi adalah $10,11 \mathrm{Mpa}$, 10,11 Mpa, 9,94 Mpa dan 8,86 Mpa untuk L2, L3, L4 dan L5. Dari grafik pada gambar 8b, diperoleh

persamaan $y=-0,7667 x^{2}+1,4778 x+9,7535$ dengan $R^{2}=0,2056$. Sehingga didapat kuat tarik rata-rata untuk tiap-tiap variasi adalah 10,36 Mpa, 10,46 Mpa, 10,16 Mpa d S an 9,64 Mpa untuk $\mathrm{C} 06, \mathrm{C} 1, \mathrm{C} 16$ dan $\mathrm{C} 2$.

\subsection{Kuat Lentur}

Dari hasil uji lentur balok beton umur 28 hari maka diperoleh nilai kuat lentur balok beton terbesar adalah untuk benda uji dengan penambahan galvanis model linting yaitu L5 dengan nilai kuat lentur balok sebesar 7,03 MPa dengan peningkatan kuat lentur sebesar $77,53 \%$ dari beton tanpa penambahan galvanis.
Secara rinci hasil kuat lentur balok beton dapat dilihat pada tabel 6 dan gambar 9 .

Tabel 6. Nilai Kuat Lentur Balok Beton

\begin{tabular}{cccc}
\hline $\begin{array}{c}\text { Benda } \\
\text { Uji }\end{array}$ & $\begin{array}{c}\text { Nilai } \\
\text { Uji } \\
\text { Lentur } \\
(\mathrm{MPa})\end{array}$ & $\begin{array}{c}\text { Peningkatan } \\
\text { Lentur Balok } \\
\text { Beton } \\
\text { Terhadap O } \\
(\%)\end{array}$ & $\begin{array}{c}\text { Peningkatan } \\
\text { Lentur Balok } \\
\text { Beton } \\
\text { Terhadap G } \\
(\%)\end{array}$ \\
\hline O & 3,96 & 0 & 0 \\
\hline G & 2,92 & $-26,26$ & 0 \\
\hline L2 & 4,18 & 5,56 & 43,15 \\
\hline L3 & 6,41 & 61,87 & 119,52 \\
\hline L4 & 2,01 & $-49,24$ & $-31,16$ \\
\hline L5 & 7,03 & 77,53 & 140,75 \\
\hline C06 & 5,41 & 36,62 & 85,27 \\
\hline C1 & 3,6 & $-9,09$ & 23,29 \\
\hline C16 & 2,38 & $-39,9$ & $-18,49$ \\
\hline C2 & 4,7 & 18,69 & 60,96 \\
\hline
\end{tabular}

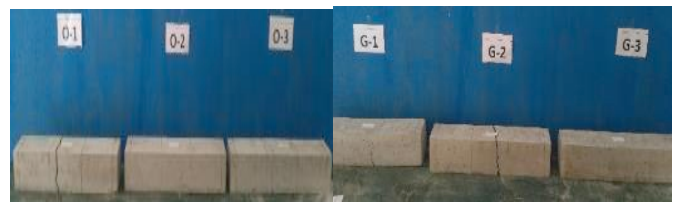

(a)

(b)

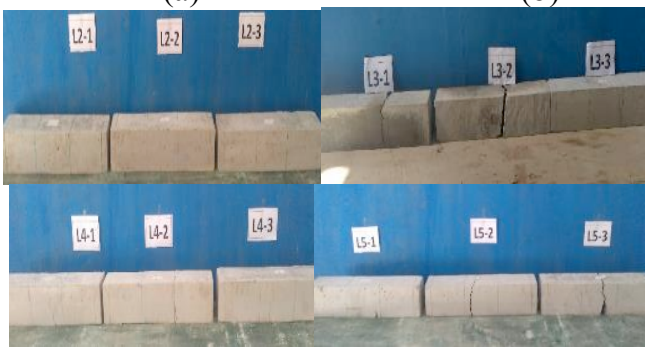

(c)

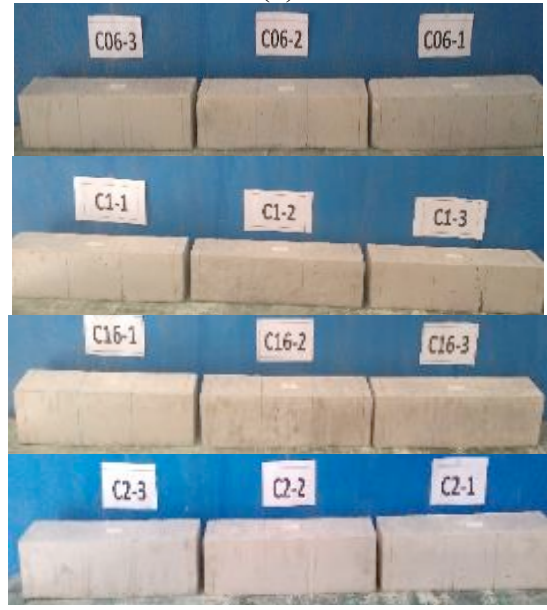

(d) 
Gambar 9. Balok Beton Setelah Uji Lentur: (a) Beton Normal, (b) Galvanis $5 \mathrm{~cm}$, (c) Linting dan (c) Spiral

Dari gambar 9 terlihat bahwa retak yang terjadi berada di $1 / 3$ tengah bentang balok untuk semua benda uji, baik benda uji beton normal, benda uji dengan penambahan kawat galvanis $5 \mathrm{~cm}$, dan benda uji dengan galvanis model linting serta crimped.

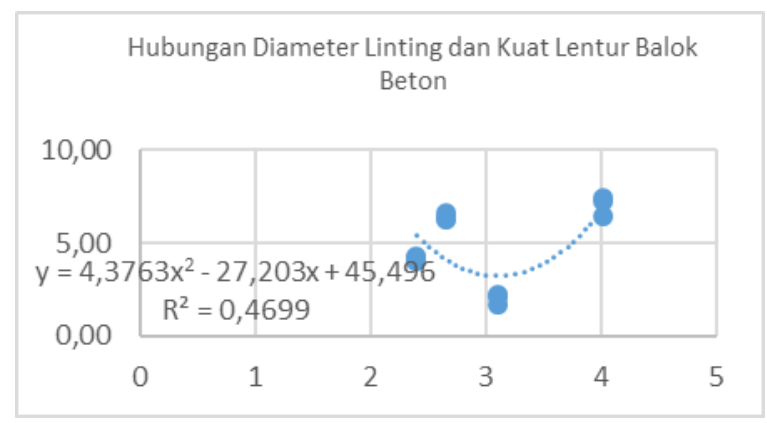

(a)

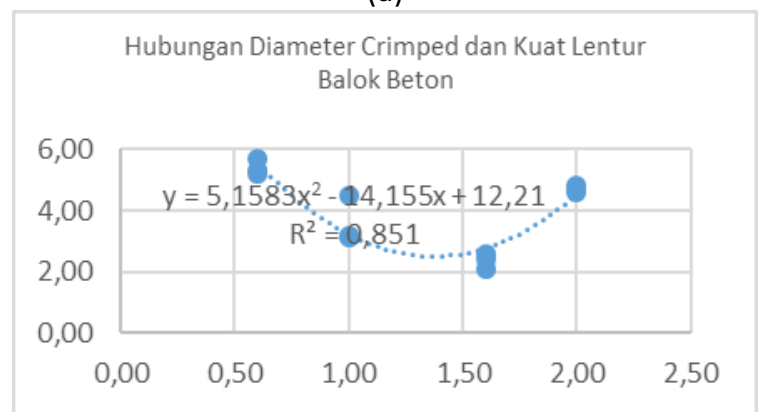

(b)

Gambar 10. Grafik Tren Kuat Lentur: (a) Balok Model Linting dan (b) Balok Model Crimped

Dari grafik pada gambar 10a, diperoleh persamaan

$y=4,3763 x^{2}-27,203 x+45,496$ dengan $R^{2}=0,4699$. Sehingga didapat kuat lentur rata-rata umur 28 hari untuk tiap-tiap variasi adalah 5,42 Mpa, 4,14 Mpa, 3,22 Mpa dan 6,86 Mpa untuk L2, L3, L4 dan L5. Dari grafik pada gambar $10 \mathrm{~b}$, diperoleh persamaan $y=5,1583 x^{2}-14,155 x+12,21$ dengan $R^{2}=0,851$. Sehingga didapat kuat lentur ratarata untuk tiap-tiap variasi adalah 5,57 $\mathrm{MPa}$, 3,21 MPa, 2,77MPa dan 4,53 Mpa untuk C06, $\mathrm{C} 1, \mathrm{C} 16$ dan $\mathrm{C} 2$.

\section{Kesimpulan}

Kesimpulan dari penelitian ini adalah:
1. Nilai kuat tekan rata-rata beton umur 14 hari adalah 19,83 MPa; 19,76 MPa; 27,68 $\mathrm{MPa} ; 24,27 \mathrm{MPa}$; 20,58 MPa; 18,89 MPa; 26,42 MPa; 25,71 MPa; 24,97 MPa dan 22,63 MPa masing-masing untuk benda uji OA, GA, L2A, L3A, L4A, L5A, C06A, C1A, C16A, dan C2A.

2. Nilai kuat tekan rata-rata beton umur 28 hari adalah 18,30 $\mathrm{MPa} ; 18,08 \mathrm{MPa} ; 22,40$ $\mathrm{MPa} ; 21,82 \mathrm{MPa} ; 18,25 \mathrm{MPa}$; 17,85 MPa; 18,93 $\mathrm{MPa} ; 19,51 \mathrm{MPa} ; 19,41 \mathrm{MPa}$ dan 21,88 MPa masing-masing untuk benda uji OB，GB，L2B，L3B，L4B，L5B，C06B, C1B, C16B, dan C2B.

3. Nilai kuat tarik belah rata-rata beton umur adalah 8,58 MPa; 10,26 MPa; 10,28 MPa; 9,79 $\mathrm{MPa} ; 10,11 \mathrm{MPa} ; 8,83 \mathrm{MPa} ; 9,84$ $\mathrm{MPa}$; 9,91 MPa; 8,77 $\mathrm{MPa}$, 8,91 MPa; 10,37 $\mathrm{MPa} ; 10,44 \mathrm{MPa} ; 10,18 \mathrm{MPa}$ dan 9,63 MPa masing-masing untuk benda uji BO, BG, BL2, BL3, BL4, BL5, BS06, BS1, $\mathrm{BS} 16, \mathrm{BS} 2$, BC06, BC1, BC16, dan BC2.

4. Nilai kuat lentur rata-rata beton adalah 3,96 $\mathrm{MPa}$; 2,92 MPa; 4,18 MPa; 6,41 MPa; 2,01 MPa; 7,03 MPa; 2,84 MPa; 3,38 MPa; 6,18 $\mathrm{MPa} ; 4,51 \mathrm{MPa} ; 5,41 \mathrm{MPa} ; 3,60 \mathrm{MPa} ; 2,38$ $\mathrm{MPa}$ dan 4,70 MPa untuk masing-masing untuk benda uji O, G, L2, L3, L4, L5, S06, S1, S16, S2, C06, C1, C16, dan C2.

\section{Saran}

Diperlukan adanya penelitian lebih lanjut tentang persentase dari kawat galvanis dalam campuran beton.

\section{Daftar Pustaka}

[1] Abdul Azis. "Studi Tarik Belah Beton dengan Penambahan Dramix Steel Fiber", Naskah Publikasi, (2016): 1-11

[2] Ahmad Saifudin. "Pengaruh Dosis, Aspek Rasio, dan Distribusi Serat Terhadap Kuat Lentur dan Kuat Tarik Belah Beton Berserat Baja", e-Jurnal Matriks Teknik Sipil (Juni, 2015): 369-376

[3] Basuki. "Pemanfaatan Kawat Galvanis Dipasang Secara menyilang pada Tulangan Begel Balok Beton untuk Meningkatkan Kuat Lentur Balok 
JURNAL TEKNOLOGI TERPADU Vol. 6 No. 2 Oktober 2018

Beton Bertulang", Simposium Nasional RAFI XII (2013) FT UMS: S28-S36

[4] Eddy Purwanto. "Studi Kuat Lentur Beton Ringan Berserat Kawat Galvanis", Jurnal Rekayasa, (2011): vol 11 No.3 